\title{
Histomorphological and immunohistochemical characterization of 172 cutaneous round cell tumours in dogs ${ }^{1}$
}

\author{
Marina Rios Araújo² ${ }^{2}$ Ingred Sales Preis², Gleidice Eunice Lavalle ${ }^{3}$, Geovanni Dantas Cassali ${ }^{4}$ \\ and Roselene $\mathrm{Ecco}^{2 *}$
}

\begin{abstract}
Araújo M.R., Preis I.S., Lavalle G.E., Cassali G.D. \& Ecco R. 2012. Histomorphological and immunohistochemical characterization of 172 cutaneous round cell tumours in dogs. Pesquisa Veterinária Brasileira 32(8):772-780. Setor de Patologia Veterinária, Escola de Veterinária, Universidade Federal de Minas Gerais, Av. Antônio Carlos 6627, Belo Horizonte, MG 31270-901, Brazil. E-mail: ecco@vet.ufmg.br

This paper describes the use of a panel of antibodies (CD117, CD3, CD79a, CD45, cytokeratin, vimentin and E-cadherin) on formalin-fixed, paraffin-embedded sections of canine cutaneous round cell tumours. Neoplastic tumours were diagnosed by histology and histochemical stains and included 107 mast cell tumours, 31 cutaneous histiocytomas, two localized histiocytic sarcomas, 21 cutaneous lymphomas, three plasma cell tumours, one transmissible venereal tumour and seven unclassified round cell tumours. The histologic diagnosis was modified in $39.5 \%$ of the total 172 neoplasms. The staining for CD 45 and Ecadherin were variable, and therefore, the final diagnoses of cutaneous histiocytoma and localized histiocytic sarcoma were made based on histology in association with negative results for CD3, CD79a, CD117 and cytokeratin. The cellular origin of unclassified round cell tumours was defined in all cases. Cutaneous B-cell lymphoma and plasma cell tumours were CD79a-positive and could be distinguished from each other by the morphological characteristics. Mast cell tumours and T cell lymphoma were CD117 and CD3 positive, respectively. The positive staining for vimentin and the negative staining for CD3, CD79a, CD117 and cytokeratin favoured the diagnosis of transmissible venereal tumours. Thus, the final diagnosis of cutaneous round cell tumours should be based on the interpretation of immunohistochemical results together with the cellular morphology observed by histology. Therefore, more studies to optimize the specific markers in formalin-fixed, paraffinembedded tissues (especially for histiocytes) are required for definitive diagnosis of round cell tumours in dogs.
\end{abstract}

INDEX TERMS: Dogs, skin, round-cells tumours, immunohistochemistry, CD117, CD3, CD79a.

RESUMO.- [Caracterização histomorfológica e imuno-histoquímica de 172 neoplasias cutâneas de células redondas em cães.] Este trabalho descreve o uso de um painel de anticorpos (CD117, CD3, CD79a, CD45, citoqueratina, vimentina e e-caderina em tecidos formalizados e parafinizados para o diagnóstico de neoplasias de célu-

\footnotetext{
${ }^{1}$ Received on December 12, 2011.

Accepted for publication on May 15, 2012.

${ }^{2}$ Departamento de Clínica e Cirurgia Veterinária, Escola de Veterinária, Universidade Federal de Minas Gerais (UFMG), Avenida Antônio Carlos 6627, Pampulha, Belo Horizonte, MG 31270-901, Brazil. *Corresponding author: ecco@vet.ufmg.br

${ }^{3}$ Hospital Veterinário, Escola de Veterinária, UFMG, Belo Horizonte, MG.

${ }^{4}$ Laboratório de Patologia Comparada, Instituto de Ciências Biológicas, UFMG, Belo Horizonte, MG.
}

las redondas em cães. Os tumores foram diagnosticados usando-se a histopatologia e a marcação imuno-histoquímica. Foram incluídos 107 mastocitomas, 31 histiocitomas cutâneos, 2 sarcomas histiocíticos localizados, 21 linfomas cutâneos, 3 plasmocitomas, 1 tumor venéreo transmissível e 7 tumores de células redondas não classificados. 0 diagnóstico histológico foi modificado em $39,5 \%$ do total de 172 neoplasias. A marcação do anticorpo CD45 e E-caderina foi variável e, nesse sentido, o diagnóstico final de histiocitoma cutâneo e sarcoma histiocítico localizado foi baseado na histologia em associação com os resultados negativos para CD3, CD79a, CD117 e citoqueratina. A origem celular dos tumores de células redondas não classificados foi definida em todos os casos. Linfoma cutâneo de célula B e plasmocitoma foram positivos para CD79a e 
foram distinguidos entre si pelas características morfológicas. Marcação positiva para vimentina e negativa para CD3, CD79a, CD117 e citoqueratina favoreceram o diagnóstico dos tumores venereos transmissíveis. Assim, o diagnóstico final dos tumores de células redondas foram baseados na interpretação dos resultados da imuno-histoquímica em conjunto com a avaliação das características morfológicas observadas na histologia. Finalmente, mais estudos em relação à padronização de marcadores específicos para tecidos parafinizados (especialmente para histiócitos) são necessários para o diagnóstico definitivo das neoplasias de células redondas em cães.

TERMOS DE INDEXAÇÃO: Cães, pele, neoplasias, celulas redondas, imunoistoquimica, CD117, CD3 e CD79a .

\section{INTRODUCTION}

The skin is one of the most common sites of neoplasms and accounts for $9.5 \%$ to $51 \%$ of all tumours in dogs (Bronden et al. 2010). Cutaneous round cell tumours may have a similar morphological appearance, and a diagnosis based only on routine histopathology is often challenging (Fernandez et al. 2005). Among these neoplasms are mast cell tumours (MCT) with intermediate differentiation, or grade II, mast cell tumours poorly differentiated, or grade III, cutaneous T-cell lymphoma (CTL), cutaneous B-cell lymphoma (CBL), plasma cell tumours (PCT), cutaneous histiocytomas (HCT) and transmissible venereal tumours (TVT) (Goldschimidt \& Hendrick 2002). Accurate diagnosis is essential to determine a prognosis and treatment (Fernandez et al. 2005). Immunohistochemistry (IHC) has been proven to be one of the most important ancillary techniques in the characterization of neoplastic diseases in veterinary medicine, as oncologists demand more specific diagnoses (Ramos-Vara et al. 2008).

MCTs are one of the most common neoplasms in dogs, comprising $7 \%$ to $21 \%$ of all skin tumours (Rothwell et al. 1987, Yager \& Wilcock 1994). These tumours are routinely graded for malignancy, based on histomorphological characteristics (Patnaik et al. 1984). However, the typical intracytoplasmic granules of mast cells are more difficult to identify using histology and histochemical stains (Giemsa or toluidine blue) in tumours with intermediate differentiation (grade II) and poor differentiation (grade III), which often makes the diagnosis more difficult (Patnaik et al. 1984). Recently, CD117 antibody, or c-KIT, has been used as an immunohistochemical specific marker for mast cells, supporting the diagnosis of less differentiated MCTs (Reguera et al. 2000). Now, three KIT-staining patterns have been proposed: membrane-associated staining (KIT I), focal-to-stippled cytoplasmic staining with decreased membrane-associated staining (KIT II), and diffuse cytoplasmic staining, (KIT III) (Kiupel et al. 2004). Apparently, tumours with the most aberrant expression (cytoplasmic staining/ KIT II or KIT III) have a worse prognosis (Kiupel et al. 2004, Webster et al. 2006).

Skin neoplasms involving T or B lymphocytes are uncommon in dogs (Day 1995). Cutaneous lymphomas (CLs) are classified into epitheliotropic or non-epitheliotropic according to their morphological appearance (Gross et al. 2006). Cutaneous epitheliotropic lymphomas have a wide variety of clinical presentations and are characterized by the infiltration of neoplastic T lymphocytes with a specific tropism for the epidermis and adnexal structures (Moore et al. 2009, Fontaine et al. 2010). Non-epitheliotropic forms of cutaneous lymphoma are less common than epitheliotropic forms. The vast majority of cutaneous canine non-epitheliotropic lymphomas have $\mathrm{T}$ cell origin (Gross et al. 2006). Cutaneous B-cell non-epitheliotropic lymphomas are extremely rare (Day 1995). Similar to what occurs in humans, the determination of the immunophenotype of lymphoma in dogs has become essential because of the relationship to biological behavior and response to therapy (Fontaine et al. 2010, Fournel-Fleury et al. 2002). Currently, the immunohistochemical markers most commonly used to characterize $\mathrm{T}$ and $\mathrm{B}$ lymphocytes in formalin-fixed, paraffin-embedded tissues include CD3 (Fournel-Fleury et al. 2002) and CD79a (Milner et al. 1996), respectively.

The extramedullary PCTs constitute a neoplastic proliferation of plasma cells without bone marrow involvement. Cutaneous PCTs are uncommon and are usually benign (Jacobs et al 2002). Immunohistochemical markers such as CD79a (Schrenzel et al. 1998) and immunoglobulins (Platz et al. 1999) have been used as ancillaries in the diagnosis of this neoplasm. Variable immunohistochemical expression of the CD79a antigen has been found in PCTs, and positive staining CD79a was present in $56.2 \%$ to $80 \%$ of cases studied (Schrenzel et al. 1998, Ramos-Vara et al. 1998, Ramos-Vara et al. 2007). The CBL also can be stained by CD79a and immunoglobulin markers. However, cutaneous PCTs and CBL can be distinguished by histomorphologic appearance and clinical course (Brunnert \& Altman 1991). Currently, the antibody MUM-1 has been indicated for specific diagnostic of plasma cell tumours (Ramos-Vara et al. 2007).

HCT is a benign neoplasm derived from Langerhans cells (Baines et al. 2008). The immunophenotypic markers of Langerhans cells include MHC-I, MHC-II, CD1a, CD1c, CD11b, CD11c, CD18, CD44, CD45, CD45RA, CD49d, ICAM-1 and E-cadherin (Baines et al. 2008, Ginn et al. 2007, Ramos-Vara \& Miller 2011). However, most of these antibodies must be used in fresh or frozen tissue, which is not often available to the veterinary. Only the CD45, CD45RA, CD11d, CD18 and E-cadherin antibodies can be used in formalin-fixed, paraffin-embedded tissues (Affolter \& Moore 2002, Gross et al. 2006, Fulmer \& Mauldin, 2007).

TVTs, occasionally also referred to as canine transmissible sarcoma or Sticker tumours, have been recognised only in dogs (Park et al. 2006, Schlafer \& Miller 2007). They are transmitted by viable tumour cells spreading from infected dogs or bitches during coitus or by licking or rubbing (Gross et al. 2006). It is suggested that natural cutaneous implantation occurs in bites or other wounds (Schlafer \& Miller 2007). Specific TVT cell markers have not been described, but immunostaining for vimentin (Pereira et al. 2000), lysozyme (Park et al., 2006), CD45 (Gross et al. 2006) and CD45RA (Gross et al. 2006) associated with histomorphological analysis support the diagnosis of this neoplasm. 
This study evaluated a panel of immunohistochemical stains as an additional technique for the diagnosis of 172 cutaneous round cell tumours in dogs.

\section{MATERIALS AND METHODS}

One hundred and seventy-two archival canine cutaneous round cell tumours were selected from those diagnosed between 1996 and 2010 at the Laboratory of Veterinary Pathology, Veterinary School, Universidade Federal de Minas Gerais, Brazil. All the tumours had been diagnosed using histopathology, but in suspected cases of mast cell tumours, histochemical (Giemsa) stains were also used. The tumours selected included 107 MCTs (35 of grade I, 29 of grade II and 43 of grade III, classified according to a previous study)(Patnaik et al. 1984), 31 HCTs, two localized histiocytic sarcomas (LHS), 21 CLs, three PCTs, one TVT and seven unclassified round cell tumours (URCTs).

Paraffin blocks were selected, and consecutive three-micrometre sections were obtained and mounted on silanised slides for immunohistochemical study. A panel of antibodies was used (Table 1), and the choice of antibody was based on the previous histological diagnosis. Heat-induced epitope retrieval using Dako antigen retrieval solution, pH 6.0 (Dako), was performed before dipping the sections in a water bath (20 minutes) for CD117, CD3, CD79a, CD45, cytokeratin AE1/AE3 and vimentin. For E-cadherin, the slides were incubated in an antigen retrieval solution (Dako) $(\mathrm{pH}=6.0)$ in a microprocessor-controlled pressure chamber for 2 minutes. The slides were then cooled at room temperature for 20 minutes in the antigen retrieval buffer. The sections were incubated at room temperature in $3 \%$ (vol/vol) $\mathrm{H}_{2} \mathrm{O}_{2}$ for $15 \mathrm{~min}$, in primary antibodies for $16 \mathrm{~h}$ at $4^{\circ} \mathrm{C}$ (CD117, CD79a, CD45, CD3) or for $1 \mathrm{~h}$ at room temperature (cytokeratin AE1/AE3, E-cadherin and vimentin), in a reagent containing secondary antibodies (Advance HRP link, Dako, Carpinteria-CA, USA) for $30 \mathrm{~min}$ and a polymer reagent (Advance HRP enzyme, Dako, Carpinteria-CA, USA) for 30 minutes. Between incubations, the slides were washed for $2 \times 5$ minutes in $10 \%$ phosphate-buffered saline solution. The immunoreactivity was visualized using diaminobenzidine (DAB substrate chromogen system, Dako, Carpinteria-CA, USA). The slides were then counterstained with Harris haematoxylin. Positive and negative control slides were included in each batch. As positive controls, the lung (CD45), the lymph node (CD79a) and the thymus (CD3) were used. For CD117, cytokeratin AE1/AE3, E-cadherin and vimentin, the self-tissue was used as an internal control. Negative controls were assessed by using normal serum (Ultra V block, Labvision, Fremont, CA, USA) to replace the primary antibody.

The immunostains for CD79a, CD45, CD3, cytokeratin AE1/ $\mathrm{AE} 3, \mathrm{E}$-cadherin and vimentin were evaluated qualitatively as positive $(+)$ or negative $(-)$. The MCTs were classified according to their KIT-staining patterns (Kiupel et al. 2004): membrane-associated staining (KIT I), focal-to-stippled cytoplasmic staining with

Table 1. Panel of antibodies used for immunohistochemistry

\begin{tabular}{|c|c|c|c|}
\hline Target antigen & Clone & Dilution & Manufacturer \\
\hline CD117 (c-KIT) & --- & $1: 800$ & Dako (Carpinteria/CA, USA) \\
\hline $\mathrm{Cl}$ & HM47/A9 & & DBS $(1$ \\
\hline CD45 & CA1210C12 & & $\begin{array}{l}\text { sity of California, Davis/ } \\
\text { A }\end{array}$ \\
\hline CD3 & CD3-12 & $1: 500$ & $\begin{array}{l}\text { University of California, Davis/ } \\
\text { CA, USA }\end{array}$ \\
\hline $\begin{array}{l}\text { Cytokeratin AE1/ } \\
\text { AE3 }\end{array}$ & AE1/AE3 & $1: 100$ & Dako (Carpinteria/CA, USA) \\
\hline E-caderin & $4 \mathrm{~A} 2 \mathrm{C} 7$ & $1: 60$ & Invitrogen (Camarillo/CA, USA) \\
\hline Vimentin & V9 & $1: 50$ & Dako (Carpinteria/CA, USA) \\
\hline
\end{tabular}

decreased membrane-associated staining (KIT II) and diffuse cytoplasmic staining (KIT III). Each MCT was assigned one of these three staining patterns based on the highest staining pattern (staining patterns I versus II versus III) present in at least $10 \%$ (estimated based on 100 neoplastic cells in a high-power field) of the neoplastic cell population or present in large clusters of neoplastic cells within the tumour. Expected results for each tumour type are summarized in Table 2.

All procedures were performed under the guidelines and with the approval of the Ethics Committee in Animal Experimentation at Universidade Federal de Minas Gerais, protocol 171/2009.

Table 2. Expected immunohistochemical results for canine cutaneous round cell tumours

\begin{tabular}{cccccccc}
\hline & CD117 & CD3 & CD79a & CD45 & CK & E-cad & Vim \\
\hline MCT & + & - & - & + & - & - & + \\
HCT & - & - & - & $+/-$ & - & $+/-$ & - \\
PCT & - & - & $+/-$ & - & - & - & + \\
CTL & - & + & - & $+/-$ & - & - & - \\
CBL & - & - & + & $+/-$ & - & - & - \\
TVT & - & - & - & $+/-$ & - & - & + \\
LHS & - & - & - & $+/-$ & - & $+/-$ & +
\end{tabular}

$\overline{\mathrm{MCT}}=$ mast cell tumour; $\mathrm{HCT}=$ cutaneous histiocytoma; $\mathrm{PCT}=$ plasma cell tumour; $\mathrm{CTL}=$ cutaneous $\mathrm{T}$ cell lymphoma; $\mathrm{CBL}=$ cutaneous $\mathrm{B}$ cell lymphoma; TVT = transmissible venereal tumour; LHS = localized histiocytic sarcoma; + positive; - negative; +/- variable; $\mathrm{CK}=$ cytokeratin AE1/AE3; E-cad = E-cadherin; Vim = vimentin

\section{RESULTS}

The stains for CD45 and E-cadherin were variable, and therefore, the final diagnosis of HCT and LHS were made based on histology in association with the negative results for CD3, CD79a, CD117 and cytokeratin AE1/AE3. Thus, CTL, CBL, PCT, MCT and tumour or basal cell carcinoma were ruled out based on the negative staining for CD3, CD79a, CD117 and cytokeratin AE1/AE3, respectively. The staining for cytokeratin AE1/AE3 was used in the neoplasms in which cords of cells were observed arranged near and perpendicular to the epidermis, similar to the tumour or basal cell carcinoma. The results of the panel of antibodies for all the tumours and the final diagnoses are summarized in Table 3.

\section{Mast cell tumours}

Of the 107 tumours that were diagnosed histologically as MCTs, $78(72.9 \%)$ were confirmed by IHC. All except one $(34 / 35)$ of the MCTs in grade I, $(27 / 29)$ grade II and $(17 / 41)$ grade III were positive for CD117 and were classified as pattern KIT I (42/78, 53.85\%) (Figure 1), pattern KIT II $(24 / 78,30.77 \%)$ (Figure 2) and pattern KIT III $(12 / 78,15.38 \%)$.

Nine HCTs (Figure 3) and one CL that had been diagnosed histologically were positive for CD117 and defined as MCTs. These tumours were negative for CD45, CD3 and CD79a.

\section{Histiocytoma}

Of the 31 tumours that were diagnosed histologically as HCT, eight $(25.81 \%)$ were confirmed. Seventeen tumours not diagnosed by histology as HCT were classified as HCT using CD45 and E-cadherin (Figure 4) as markers, in association with morphological characteristics (especially large 
Table 3. Immunohistochemical stain panel with results for 172 canine cutaneous round cell tumours

\begin{tabular}{|c|c|c|c|c|c|c|c|c|c|}
\hline $\begin{array}{l}\text { Histologic } \\
\text { diagnosis }\end{array}$ & $\begin{array}{c}\text { No } \\
\text { tumours }\end{array}$ & $\begin{array}{c}\text { Final } \\
\text { diagnosis }\end{array}$ & CD117 & CD3 & CD7 & CD45 & $5 \mathrm{CK}$ & E-cad & Vim \\
\hline MCT I & 24 & MCT & KIT I & ND & ND & ND & ND & ND & ND \\
\hline MCT I & 10 & MCT & KIT II & ND & ND & ND & ND & ND & ND \\
\hline MCT II & 16 & MCT & KIT I & ND & ND & ND & ND & ND & ND \\
\hline MCT II & 7 & MCT & KIT II & ND & ND & ND & ND & ND & ND \\
\hline MCT II & 4 & MCT & KIT III & ND & ND & ND & ND & ND & ND \\
\hline MCT III & 2 & MCT & KIT I & ND & ND & ND & ND & ND & ND \\
\hline MCT III & 7 & MCT & KIT II & ND & ND & ND & ND & ND & ND \\
\hline MCT III & 8 & MCT & KIT III & ND & ND & ND & ND & ND & ND \\
\hline MCT III & 6 & HCT & - & - & - & - & - & + & ND \\
\hline MCT III & 1 & HCT & - & - & - & - & - & - & ND \\
\hline MCT III & 1 & LHS & - & - & - & + & - & ND & ND \\
\hline MCT III & 1 & LHS & - & - & - & - & - & ND & ND \\
\hline MCT II & 1 & CTL & - & + & - & + & ND & ND & ND \\
\hline MCT III & 3 & CTL & - & + & - & + & ND & ND & ND \\
\hline MCT III & 9 & CTL & - & + & - & - & ND & ND & ND \\
\hline MCT I & 1 & PCT & - & - & - & - & ND & ND & ND \\
\hline MCT II & 1 & PCT & - & - & + & - & ND & ND & ND \\
\hline MCT III & 1 & PCT & - & - & + & - & ND & ND & ND \\
\hline MCT III & 1 & PCT & - & - & - & - & ND & ND & ND \\
\hline MCT III & 1 & TVT & - & - & - & - & - & ND & + \\
\hline MCT III & 1 & TVT & - & - & - & + & ND & ND & + \\
\hline MCT III & 1 & TVT & - & - & - & - & ND & ND & + \\
\hline HCT & 4 & HCT & - & - & - & + & - & + & ND \\
\hline HCT & 3 & HCT & - & - & - & - & - & + & ND \\
\hline HCT & 1 & HCT & - & - & - & - & - & - & ND \\
\hline HCT & 1 & MCT & KIT I & - & - & - & ND & ND & ND \\
\hline HCT & 3 & MCT & KIT II & - & - & - & ND & ND & ND \\
\hline HCT & 5 & MCT & KIT III & - & - & - & ND & ND & ND \\
\hline HCT & 1 & LHS & - & - & - & - & ND & - & ND \\
\hline HCT & 4 & CTL & ND & + & - & + & ND & ND & ND \\
\hline HCT & 4 & CTL & ND & + & - & - & ND & ND & ND \\
\hline HCT & 1 & PCT & - & - & - & - & ND & ND & ND \\
\hline HCT & 1 & PCT & - & - & + & - & ND & ND & ND \\
\hline HCT & 1 & PCT & ND & - & - & - & ND & ND & ND \\
\hline HCT & 1 & TVT & ND & - & - & - & - & ND & + \\
\hline HCT & 1 & TVT & - & - & - & - & - & ND & + \\
\hline $\mathrm{CL}$ & 7 & CTL & ND & + & - & + & ND & ND & ND \\
\hline $\mathrm{CL}$ & 5 & CTL & ND & + & - & - & ND & ND & ND \\
\hline CL & 1 & CBL & ND & - & + & - & ND & ND & ND \\
\hline CL & 2 & HCT & - & - & - & - & - & + & ND \\
\hline CL & 1 & НCT & - & - & - & + & - & - & ND \\
\hline CL & 3 & HCT & - & - & - & - & - & - & ND \\
\hline CL & 1 & LHS & - & - & - & - & ND & ND & ND \\
\hline CL & 1 & MCT & KIT III & - & - & - & ND & ND & ND \\
\hline LHS & 1 & LHS & - & - & - & + & ND & ND & ND \\
\hline LHS & 1 & LHS & - & - & - & - & ND & ND & ND \\
\hline PCT & 2 & PCT & ND & - & + & - & ND & ND & ND \\
\hline PCT & 1 & HCT & - & - & - & - & - & - & ND \\
\hline TVT & 1 & TVT & ND & - & - & + & ND & ND & + \\
\hline URCT & 3 & HCT & - & - & - & - & - & - & ND \\
\hline URCT & 1 & CBL & ND & - & + & - & ND & ND & ND \\
\hline URCT & 1 & CBL & - & - & + & + & ND & ND & ND \\
\hline URCT & 1 & CTL & - & + & - & + & ND & ND & ND \\
\hline URCT & 1 & TVT & - & - & - & - & - & ND & + \\
\hline
\end{tabular}

MCT I = mast cell tumour grade I; MCT II = mast cell tumour grade II; MCT III = mast cell tumour grade III HCT = cutaneous histiocytoma; LHS = localised histiocytic sarcoma; $\mathrm{CL}=$ cutaneous lymphoma; CTL = cutaneous T-cell lymphoma; $\mathrm{CBL}=$ cutaneous $\mathrm{B}$-cell lymphoma; $\mathrm{PCT}=$ plasma cell tumour; TVT $=$ transmissible venereal tumour; URCT $=$ unclassified round cell tumour; ND = not done; + positive; - negative; KIT I = membrane-associated staining; KIT II = focal-to-stippled cytoplasmic staining with decreased membrane-associated staining; KIT III = diffuse cytoplasmic staining; $\mathrm{CK}=$ cytokeratin AE1/AE3; E-cad = E-cadherin; Vim = vimentin

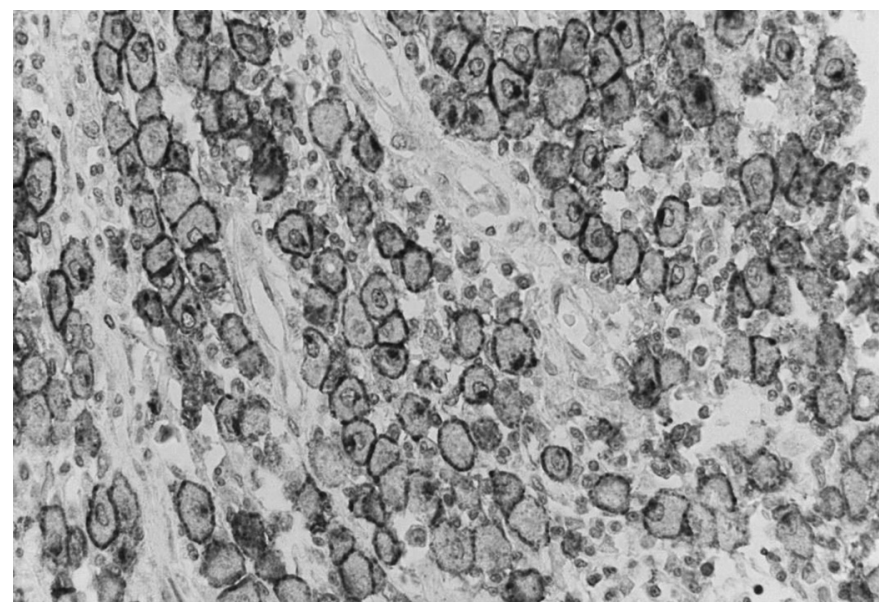

Fig.1. Skin, Dog 55: Mast cell tumour. Neoplastic mast cells characterized by membrane-associated staining with little or no cytoplasmic staining, KIT-staining pattern I. Chromogen DAB, Mayer's Haematoxylin counter stain, 600x.

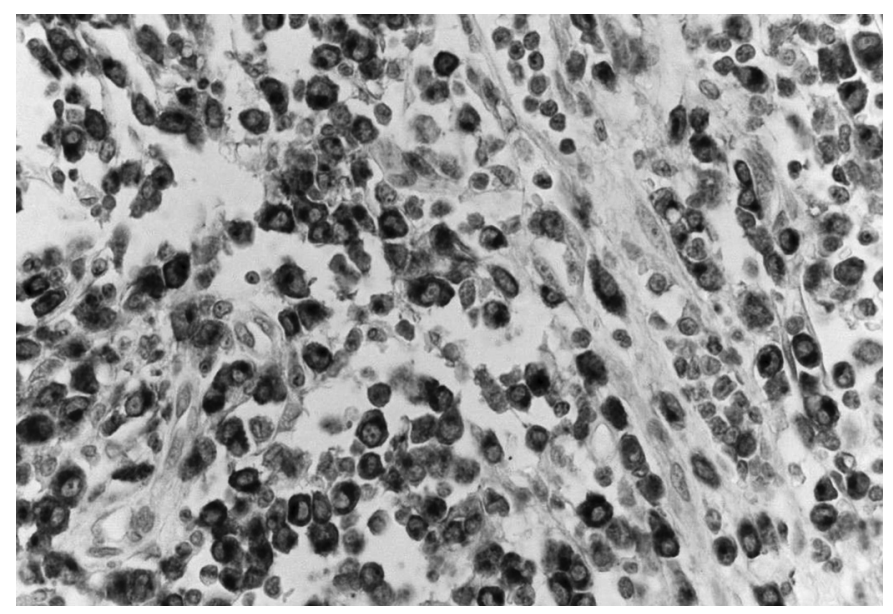

Fig.2. Skin, Dog 142: Mast cell tumour. Neoplastic mast cells characterized by intense focal or stippled cytoplasmic staining, KIT-staining pattern II. Chromogen DAB, Mayer's Haematoxylin counter stain, $600 \mathrm{x}$.

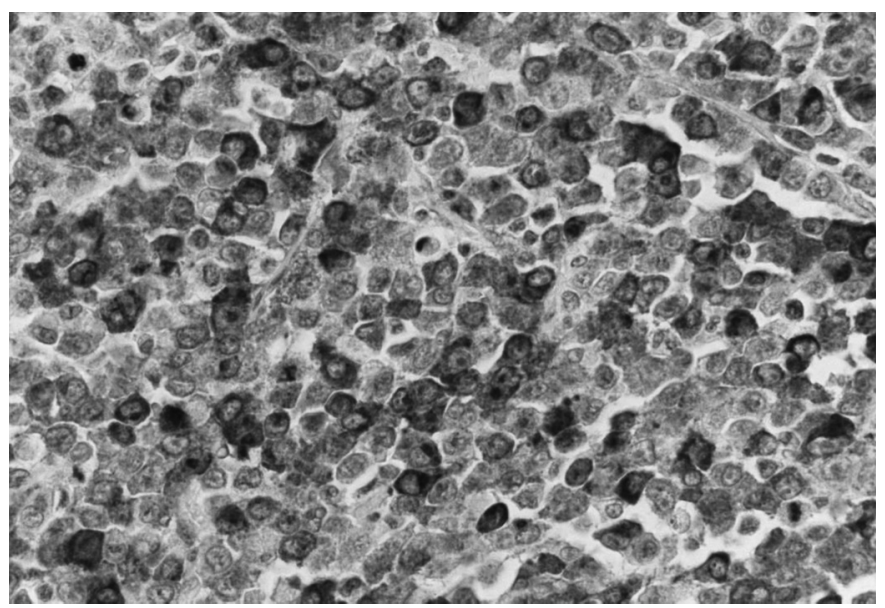

Fig.3. Skin, Dog 12: Mast cell tumour. Neoplastic mast cells characterized by diffuse cytoplasmic staining, KIT-staining pattern III. Chromogen DAB; Mayer's Haematoxylin counter stain, 600x. 

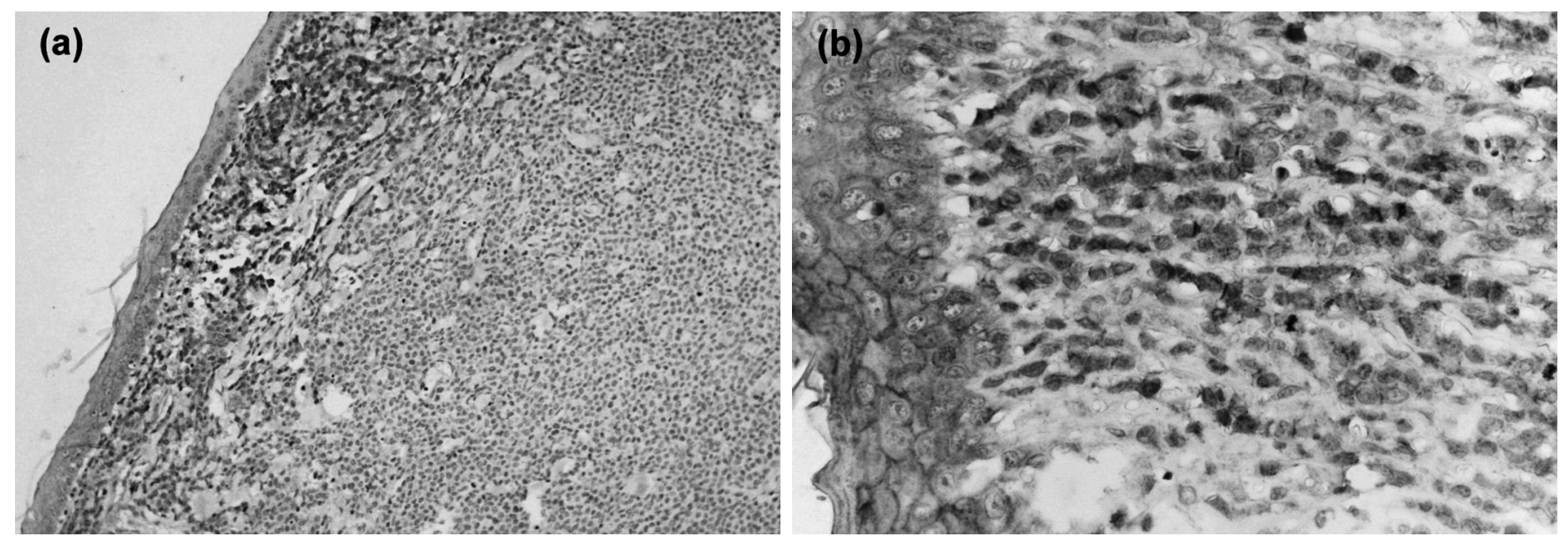

Fig.4. Skin, Dog 41: Cutaneous histiocytoma. (a) Magnification 200x, immunostaining positive for E-cadherin in the epidermis (internal control) and in the histiocytes of the superficial dermis. The dense deep portion lacks expression for E-cadherin. (b) Magnification $600 x$, details of positive stain of the histiocytes in the superficial dermis. Chromogen DAB, Mayer's Haematoxylin counter stain.

round cells with abundant amphophilic cytoplasm and nucleus round to indented): seven (41.2\%) MCTs, six (35.3\%) CLs, one (5.9\%) PCT and three (17.6\%) URCTs.

\section{Localized histiocytic sarcoma}

The two tumours that were diagnosed histologically as LHS were confirmed. Two MCTs (50.0\%), a CL (25\%) and a HCT $(25 \%)$ that had been diagnosed histologically were defined as LHS using IHC (negative for CD117, CD3 and CD79). The differentiation between the HCT and LHS was performed by observation of the morphology and cellular characteristics of malignancy.

\section{Cutaneous lymphoma}

Of the 21 tumours that were diagnosed histologically as CL, $13(61.9 \%)$ were confirmed by IHC. CTLs were the most common $(12 / 13,92.3 \%)$ based on positive CD3 staining, and only one CBL $(1 / 13,7.69 \%)$ was observed and characterized by staining positive for CD79a. Of the 12 tumours diagnosed as CTL, seven (58.33\%) were classified

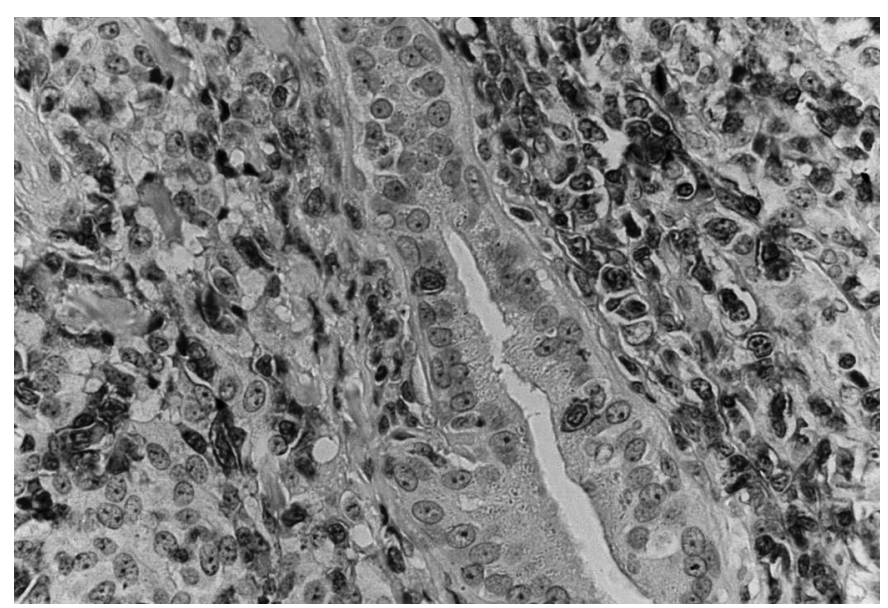

Fig.5. Skin, Dog 22: Lymphoma T-cell epitheliotropic. Neoplastic lymphocytes stained positive for CD3 invading the apocrine gland epithelium (epitheliotropic). Chromogen DAB, Mayer's Haematoxylin counter stain, 600x.

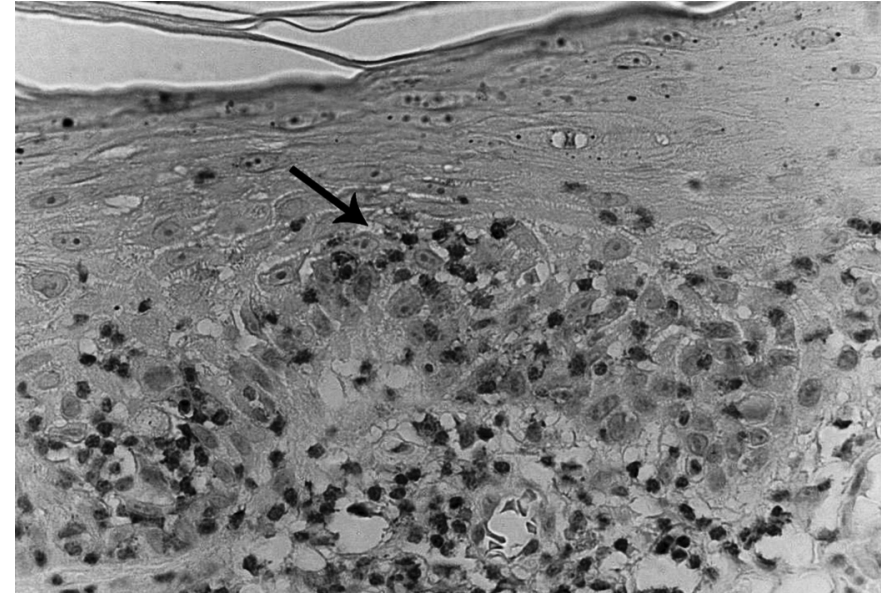

Fig.6. Skin, Dog 13: Lymphoma T-cell epitheliotropic. Neoplastic lymphocytes stained positive for CD3 invading the epidermis (arrow) and the dermis. Chromogen DAB, Mayer's Haematoxylin counter stain, $200 \mathrm{x}$.

as epitheliotropic T-cell lymphoma (Figure 5 and 6) and were characterized by the presence of tumour cells staining positive for CD3 in the epidermis, arranged diffusely or in small groups (Pautrier microabscesses) and also in the epithelium of hair follicles and the apocrine and sebaceous glands. Of the 12 tumours diagnosed as CTL, three (25.0\%) were classified as non-epitheliotropic T-cell lymphoma. The tumour cells positive for CD3 were located in the superficial dermis, near the epidermis but with no close contact between them, or were located in the deep dermis. Two $(16.67 \%)$ of the 12 tumours diagnosed as CTL could not be classified as epitheliotropic or non-epitheliotropic due to ulceration of the epidermis and the hair follicles and the fact that the glands were not visible.

Twenty-two tumours diagnosed histologically as MCTs $(13 / 22,59.09 \%)$, HCTs $(8 / 22,36.36 \%)$ and URCT $(1 / 22$, $4.5 \%$ ) were defined as CLT based on positive CD3 staining. Of these 22 tumours, eight (36.36\%) were classified as lymphoma T-cell epitheliotropic, $11(50.0 \%)$ were classified as lymphoma T-cell non-epitheliotropic, and three (13.64\%) 
were not classified. Two URCTs were defined as CBLs based on positive CD79a staining. The differentiation between CBL and PCT, which can also stain positive for CD79a, was performed by evaluation of cellular morphology.

\section{Plasma cell tumours}

Of the three tumours that were diagnosed histologically as PCT, two (61.67\%) were confirmed by IHC based on staining positive for CD79a (Figure 7). Seven tumours diagnosed histologically as MCTs $(4 / 7,57.14 \%)$ and HCTs $(3 / 7,42.86 \%)$ were defined as PCT based on the IHC results (CD117 and CD3 negative) in association with histological characteristics.

\section{Transmissible venereal tumours}

One tumour that was diagnosed histologically as TVT was confirmed by IHC based on staining positive for vimentin (Figure 8). Six tumours classified histologically as MCTs $(3 / 6,50.0 \%)$, HCTs $(2 / 6,33.33 \%)$ and URCT $(1 / 6$, $16.67 \%$ ) were determined as TVT based on staining positive for vimentin and staining negative for CD3, CD79, CD117 and cytokeratin AE1/AE3.

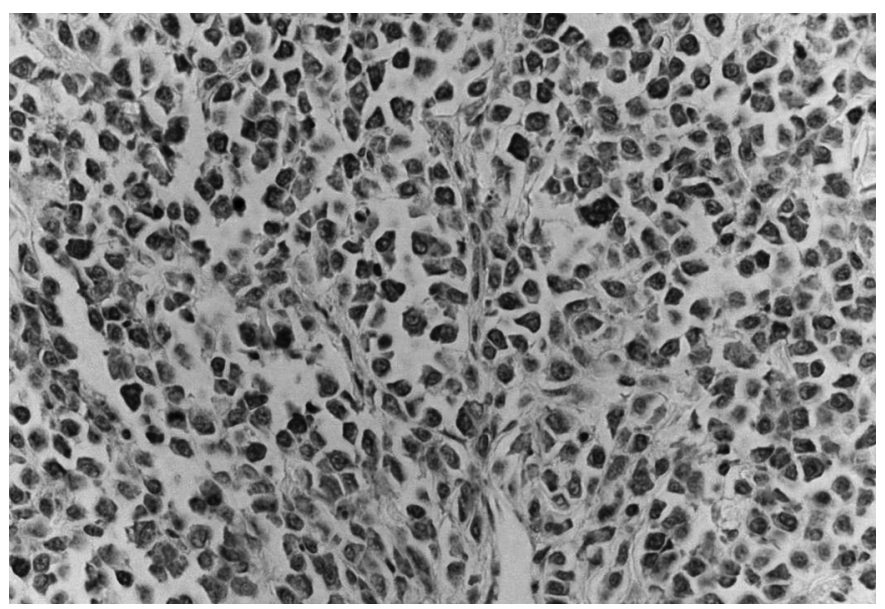

Fig.7. Skin, Dog 4: Plasma cell tumour. Neoplastic plasma cells stained positive for CD79a. Chromogen DAB, Mayer's Haematoxylin counter stain, $600 \mathrm{x}$.

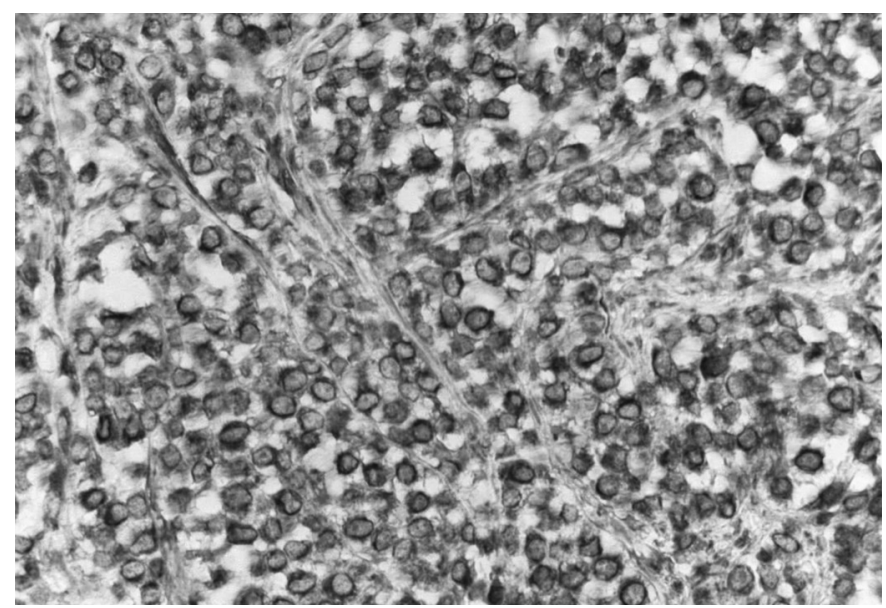

Fig.8. Skin, Dog 90: Transmissible venereal tumour. Round cells with large nucleus showing positive staining for vimentin. Chromogen DAB, Mayer's Haematoxylin counter stain, 600x

\section{Unclassified round cell tumours}

The diagnosis was obtained for all cases $(5 / 5,100.0 \%)$ of histologically unclassified round cell tumours with the support of IHC: three $(42.86 \%)$ HCTs, two $(28.57 \%)$ CBLs, one $(14.29 \%)$ CTL and one (14.29\%) TVT.

\section{DISCUSSION}

In this study, the frequency of all the cutaneous round cell tumours classified by IHC was different from the frequency of these tumours categorized by histology. The MCTs were the most commonly observed but in different proportions, $51.2 \%(88 / 172)$ by IHC versus $62.2 \%(107 / 172)$ by histology. The high prevalence of MCTs was expected because this neoplasm represents $7 \%$ to $21 \%$ of all skin tumours (Rothwell et al. 1987, Yager \& Wilcock 1994). The frequency of CL diagnosed by IHC was 1.8 times higher $(21.5 \%, 37 / 172)$ compared to histology $(12.2 \%, 21 / 172)$. The frequency of CTL $(19.8 \%, 34 / 172)$ was more common than CBL $(1.7 \%, 3 / 172)$. The frequency of HCT decreased when diagnosed with the support of IHC $(14.5 \%, 25 / 172)$ compared with histology $(18.02 \%, 31 / 172)$. In this study, the frequency of CLs was higher than HCTs. Studies on the prevalence of skin tumours in dogs show that the frequency of HCTs is greater than CLs, but in these cases, only histology was used as a diagnostic tool (Kaldrymidou et al. 2002, Pakhrin et al. 2007). The diagnosis of PCT, LHS and TVT using IHC (5.2\%, 9/172, 3.5\%, 6/172 and 4.1\%, $7 / 172$, respectively) was greater than the diagnoses using only histology $(1.74 \%, 3 / 172,1.17 \%, 2 / 172$ and $0.06 \%$, $1 / 172$, respectively).

The antibody CD117 (c-KIT), as expected, proved to be extremely useful for the diagnosis of MCTs, especially for grade III. In this study, the three patterns of KIT-staining described by Kiupel et al. (2004) were observed. Of the tumours diagnosed histologically as CL, 4.8\% (1/21) were positive for CD117 and were re-diagnosed as MCTs. Similarly, $2.9 \%(9 / 31)$ of the tumours previously diagnosed as HCT were positive for CD117 and were re-diagnosed as MCTs. In $90 \%(9 / 10)$ of these cases, cytoplasmic staining for CD117 (KIT II or KIT III) was present, indicating that the tumours were less differentiated. Histologically, the intracytoplasmic granules typical of mast cells are more difficult to visualize in tumours with intermediary differentiation (grade II) and poor differentiation (grade III) (Patnaik et al. 1984). Special stains such as toluidine blue and Giemsa are used to improve the visibility of these granules. In many cases, the granules are not seen even with the use of the histochemical stains. Thus, IHC becomes a vital tool to help histology provide a more definitive diagnosis of round cell tumours, especially in cases of poorly differentiated MCTs (Reguera et al. 2000).

CD45 is a common leukocyte antigen, and Moore et al. (1996) and Affolter \& Moore (2002) report the expression of this marker in HCTs and LHSs, respectively. In this study, approximately $20 \%(5 / 25)$ and $33.33 \%(2 / 6)$ of the tumours defined as HCTs and LHSs, respectively, were positive for CD45. The expression of CD45 is also reported in CTLs (Moore et al. 1994), CBLs (Gross et al. 2006), PCTs (Schrenzel et al. 1998), TVTs (Sharkey \& Willman 2011) 
and MCTs (Gross et al. 2006, Jakab et al. 2009). In this study, $47 \%(16 / 34)$ of the CTLs, $33.33 \%$ (1/3) of the CBLs and $28.6 \%(2 / 7)$ of the TVTs were positive for CD45. The lack of expression or weak expression of the common leukocyte antigen CD45 has been described in cases of CTLs (Affolter et al. 2009). Therefore, the most likely hypothesis that could explain the lack of positive staining for CD45 observed in this study would be that the loss of differentiation in the cells would not permit the expression of the antigen on the cell surface.

In $60 \%(15 / 25)$ of all tumours with a final diagnosis of HCT, positive staining for E-cadherin was observed. In all these cases, immunostaining was observed in tumour cells near and arranged perpendicular to the epidermis. According to Ramos-Vara \& Miller (2011), the intensity of labelling for E-cadherin in HCTs decreases with increasing distance from the epidermis due to the maturation of Langerhans cells or the immune response during tumour regression. According to Baines et al (2008), although the immunostaining for E-cadherin in HTCs is well known, Gross et al. (2006) reported that the lack of expression of this marker can be observed. In this study, 40\% (10/25) of the tumours were negative for E-cadherin, probably due to the differentiation of the tumour cells. The definitive diagnosis of tumours of histiocytic origin is challenging given the lack of specific cell markers in formalin-fixed, paraffin-embedded tissues. In a study in humans, Vos et al. (2005) $)^{37}$ demonstrated that the antibody CD163 could be an apparently specific marker for histiocytes.

The single case of LHS submitted to IHC for E-cadherin was negative. Information about immunostaining for E-cadherin in LHS is controversial. According to Gross et al (2006), these tumours do not express E-cadherin, but recently Ramos-Vara \& Miller (2011) described positive staining for E-cadherin in five histiocytic sarcomas analysed.

The cytokeratin AE1/AE3 is expressed in all tumours of epithelial origin. Basal cell tumour and basal cell carcinoma (tumours originating from the basal layer of the epidermis) have morphological characteristics similar to HCT, that is, a growth pattern near the epidermis in cords of cells arranged perpendicular to the epidermis (Gross et al. 2006). In this study, the cytokeratin was used in tumours that had those morphological characteristics and that were negative for CD45 to rule out a possible epithelial origin. None of the tumours showed reactivity for cytokeratin and CD3, CD79, CD117 as well. Thus, the final diagnosis of HCT was made by the association of the combined results of the IHC analysis and the morphological characteristics of the neoplastic cells. HCTs are constituted by proliferation of large round cells with abundant amphophilic cytoplasm and nucleus round to indented. A growth pattern is characterized by cord of cells arranged perpendicular to the epidermis (Gross et al. 2006).

Vimentin is a marker of mesenchymal cells and is expressed in the TVT (Pereira et al. 2000), in the MCT (Jakab et al. 2009, Lin et al. 2010), in the PCT (Baer et al. 1989, Schrenzel et al. 1998) and in the LHS (Azakami et al. 2006). In this study, the tumours defined as TVT by IHC were positive for vimentin in $100 \%(6 / 6)$ of the cases and positi- ve for CD45 in $28.6 \%(2 / 7)$ of the cases. All of them were negative for CD117, CD3 and CD79. The tumours submitted to immunostaining for cytokeratin AE1/AE3 also were negative. This panel of antibodies rule out the possibilities of poorly differentiated MCT, CTL, CBL, PCT or poorly differentiated carcinoma. Thus, the positive staining for vimentin favours the diagnosis of TVT. The possibility of HCT and amelanotic melanoma was also ruled out by the evaluation of the morphological characteristics of the tumour cells. The TVT neoplastic cells had large nuclei, scant cytoplasm, a high mitotic index and cellular monotony, were sometimes vacuolated, and their predominant location was in the dermis and not near and perpendicular to the epidermis, as observed in HCTs (Gross et al. 2006).

Although the reactivity of CD79a in canine PCT and CBL is well established, there are large variations in the percentage of cases and number of cells stained with this marker, with up to $80 \%$ of PCTs expressing CD79 (Schrenzel et al. 1998, Ramos-Vara et al. 1998). Other authors observed positive staining for CD79a in 59 (56.2\%) of 105 cases of PCT (Ramos-Vara et al. 2007). In the present study, the tumours defined as PCTs were positive for CD79a in 66.66\% (6/9) of the cases, and the labelling was predominantly cytoplasmic diffuse. The differentiation between the PCT and CBL, which also expressed CD79 $(3 / 3,100 \%)$, was performed by evaluation of the cellular morphology because all the PCTs had, in different proportions, well-differentiated cells characteristic of plasma cells, a perinuclear halo (Golgi zone), a peripheral nucleus, and abundant amphophilic cytoplasm, including cells with Russel's corpuscle (Mott cell), to support the diagnosis (Ginn et al. 2007).

The CD3 is a specific marker for T lymphocytes (Fournel-Fleury et al. 2002). In this study, 92\% (34/37) of the CLs were positive for CD3. The frequency of T lymphomas, T-cell epitheliotropic and non-epitheliotropic, were very close. Approximately 44\% (15/34) were classified as lymphoma T-cell epitheliotropic and $41 \%(14 / 34)$ as lymphoma T-cell non-epitheliotropic. According to Gross et al (2006) ${ }^{12}$, lymphoma T-cell non-epitheliotropic is much less common than lymphoma T-cell epitheliotropic, and the lymphoma B-cell non-epitheliotropic is still more rare.

The findings observed in this study showed that using IHC as an auxiliary tool for histology is extremely useful for pathologists who diagnose cutaneous round cell tumours. It is important to note that IHC is complementary to histolopathologic features, and the final diagnosis should be based on the interpretation of immunohistochemical results together with the cellular features seen on histopathology. The results related to the marker CD45 and E-cadherin demonstrated that, although some cases were negative for these two markers, the final diagnosis of HCT was made in association with negative staining for other markers (CD117, CD3, CD79a and cytokeratin AE1/AE3) and observation of the morphological characteristics of the tumour cells. The distinction between CBLs and PCTs, which also express CD79a, was support by morphological characteristics. Therefore, careful observation of the histological characteristics of tumour cells is extremely important to 
select the antibodies and support the interpretation of the results from IHC. Because IHC is a relatively expensive diagnostic procedure, pathologists tend to use only one or two antibodies to confirm diagnostic suspicions in some cases. Considering these conditions, CD117 is very useful to discard or confirm the diagnostic of undifferentiated mast cell tumours.

Finally, more studies on the standardization of specific markers in formalin-fixed, paraffin-embedded tissues (especially for histiocytes and transmissible venereal tumor) are required for definitive diagnosis of cutaneous round cell tumours in dogs.

Acknowledgments.- This study was supported by the Pró-Reitoria de Pesquisa da Universidade Federal de Minas Gerais (PRPq-UFMG), Conselho Nacional de Desenvolvimento Científico e Tecnológico (CNPq) and Fundação de Amparo à Pesquisa (FAPEMIG), Brasil.

\section{REFERENCES}

Affolter V.K. \& Moore P.F. 2002. Localized and disseminated histiocytic sarcoma of dendritic cell origin in dogs. Vet. Pathol. 39(1):74-83.

Affolter V.K., Gross T.L. \& Moore P.F. 2009. Indolent cutaneous T-cell lymphoma presenting as cutaneous lymphocytosis in dogs. Vet. Dermatol. 20(5/6):577-85.

Azakami D., Bonkobara M., Washizu T., Iida A., Kondo M., Kato R., Niikura Y., Iwaki S., Tamahara S., Matsuki N. \& Ono K. 2006. Establishment and biological characterization of canine histiocytic sarcoma cell lines. J. Vet. Med. Sci. 68(12):1343-1346.

Baer K.E., Patnaik A.K., Gilbertson S.R. \& Hurvitz A.I. 1989. Cutaneous plasmacytomas in dogs: A morphologic and immunohistochemical study. Vet. Pathol. 26(3):216-221.

Baines S.J., McInnes E.F. \& McConnell I. 2008. E-cadherin expression in canine cutaneous histiocytomas. Vet. Rec. 162(16):509-513.

Bronden L.B., Eriksen T. \& Kristensen A.T. 2010. Mast cell tumours and other skin neoplasia in Danish dogs: Data from the Danish Veterinary Cancer Registry. Acta Vet. Scand. 52(6). Available at <http://www.actavetscand.com/content/52/1/6> Accessed on Jan. 3, 2011.

Brunnert S.R. \& Altman N.H. 1991. Identification of immunoglobulin light chains in canine extramedullary plasmacytomas by thioflavine $\mathrm{T}$ and immunohistochemistry. J. Vet. Diagn. Invest. 3(3):245-251.

Day M.J. 1995. Immunophenotypic characterization of cutaneous lymphoid neoplasia in the dog and cat. J. Comp. Pathol. 112(1):79-96.

Fernandez N.J., West K.H., Jackson M.L. \& Kidney B.A. 2005. Immunohistochemical and Histochemical stains for differentiating canine cutaneous round cell tumors. Vet. Pathol. 42(4):437-445.

Fontaine J., Heimann M. \& Day M.J. 2010. Canine cutaneous epitheliotropic T-cell lymphoma: A review of 30 cases. Vet. Dermatol. 21(3):267-275.

Fournel-Fleury C., Ponce F., Felman P., Blavier A., Bonnefont C., Chabanne L., Marchal T., Cadore J.L., Goy-Thollot I., Ledieu D., Ghernati I. \& Magnol J.P. 2002. Canine T-cell lymphomas: A morphological, immunological, and clinical study of 46 new cases. Vet. Pathol. 39(1):92-109.

Fulmer A.K. \& Mauldin G.E. 2007. Canine histiocytic neoplasia: An overview. Can. Vet. J. 48(10):1041-1050.

Ginn P.E., Mansell J.E.K.L. \& Rakich P.M. 2007. The skin and appendages, p.553-781. In: Maxie M.G. (Ed.), Jubb, Kennedy, and Palmer's Pathology of Domestic Animals. Vol.1. Saunders Elsevier, Philadelphia.

Goldschmidt M.H. \& Hendrick M.J. 2002. Tumors of the skin and soft tissues, p.44-117. In: Meuten J.D. (Ed.), Tumors in Domestic Animals. Iowa State University Press, Ames.

Gross T.L., Ihrke P., Walder E.J. \& Affolter V.K. 2009. Skin diseases of the dog and cat: clinical and histopathologic diagnosis. $2^{\text {nd }}$ ed. Blackwell Publishing, Ames. 932p.
Jacobs R.M., Messick J.B. \& Valli V.E. 2002. Tumors of the hemolymphatic system, p.119-198. In: Meuten J.D. (Ed.), Tumors in Domestic Animals. Iowa State University Press, Ames.

Jakab C., Szász A.M., Kulka J., Schaff Z., Rusvai M., Németh T. \& Gálfi P. 2009. Cutaneous mast cell tumour within a lipoma in a boxer. Acta Vet. Hung. 57(20):263-274.

Kaldrymidou H., Leontides L., Koutinas A.F., Saridomichelakis M.N. \& Karayannopoulou M. 2002. Prevalence, distribution and factors associated with the presence and the potential for malignancy of cutaneous neoplasms in 174 dogs admitted to a clinic in northern Greece. J. Vet. Med. A, Physiol. Pathol. Clin. Med. 49(2):87-91.

Kiupel M., Webster J.D., Kaneene J.B., Miller R. \& Yuzbasiyan-Gurkan V. 2004. The use of KIT and Tryptase expression patterns as prognostic tools for canine cutaneous mast cell tumors. Vet. Pathol. 41(4):371-377.

Lin T.Y., Hamberg A., Pentecost R., Wellman M. \& Stromberg P. 2010. Mast cell tumors in a llama (Lama glama). J. Vet. Diagn. Invest. 22(5):808-811.

Milner R.J., Pearson J., Nesbit J.W. \& Close P. 1996. Immunophenotypic classification of canine malignant lymphoma on formalin-mixed paraffin wax-embedded tissue by means of CD3 and CD79a cell markers. Onderstepoort J. Vet. Res. 63(4):309-313.

Moore P.F., Affolter V.K., Graham P.S. \& Hirt B. 2009. Canine epitheliotropic cutaneous T-cell lymphoma: An investigation of T-cell receptor immunophenotype, lesion topography and molecular clonality. Vet. Dermatol. 20(5/6):569-576.

Moore P.F., Olivry T. \& Naydan D. 1994. Canine cutaneous epitheliotropic lymphoma (mycosis fungoides) is a proliferative disorder of CD8+ T cells. Am. J. Pathol. 144(2):421-429.

Moore P.F., Schrenzel M.D., Affolter V.K., Olivry T. \& Naydan D. 1996. Canine cutaneous histiocytoma is an epidermotropic Langerhans cell histiocytosis that expresses CD1 and specific f32-integrin molecules. Am. J. Pathol. 148(5):1699-1708.

Pakhrin B., Kang M.S., Bae I.H., Park M.S., Jee H., You M.H., Kim J.H., Yoon B.I., Choi Y.K. \& Kim D.Y. 2007. Retrospective study of canine cutaneous tumors in Korea. J. Vet. Sci. 8(3):229-236.

Park M.S., Kim Y., Kang M.S., Oh S.Y., Cho D.Y., Shin N.S. \& Kim D.Y. 2006. Disseminated transmissible venereal tumor in a dog. J. Vet. Diagn. Invest. 18(1):130-133.

Patnaik A.K., Ehler W.J \& Macewen E.G. 1984. Canine cutaneous mast cell tumor: Morphologic grading and survival time in 83 dogs. Vet. Pathol. 21(5):468-74.

Pereira J.S., Silva A.B. \& Martins A.L. 2000. Immunohistochemical characterization of intraocular metastasis of a canine transmissible venereal tumor. Vet. Ophthalmol. 3(1):43-47.

Platz S.J., Breuer W., Pfleghaar S., Minkus G., Hermanns W. 1999. Prognostic value of histopathological grading in canine extramedullary plasmacytomas. Vet. Pathol. 36(1):23-27.

Ramos-Vara J.A. \& Miller M.A. 2011. Immunohistochemical expression of E-cadherin does not distinguish canine cutaneous histiocytoma from other canine round cell tumors. Vet. Pathol. 48(3):758-763.

Ramos-Vara J.A., Kiupel M., Baszler T., Bliven L., Brodersen B., Chelack B., Czub S., Del Piero F., Dial S., Ehrhart E.J., Graham T., Manning L., Paulsen D., Valli V.E. \& West K. 2008. Suggested guidelines for immunohistochemical techniques in veterinary diagnostic laboratories. J. Vet. Diagn. Invest. 20(4):393-413.

Ramos-Vara J.A., Miller M.A. \& Valli V.E. 2007. Immunohistochemical detection of multiple myeloma 1/interferon regulatory factor 4 (MUM1/ IRF-4) in canine plasmacytoma: Comparison with CD79a and CD20. Vet. Pathol. 44(6):875-884.

Ramos-Vara J.A., Miller M.A., Pace L.W., Linke R.P., Common R.S. \& Watson G.L. 1998. Intestinal multinodular Al-amyloid deposition associated with extramedullary plasmacytoma in three dogs: Clinicopathological and immunohistochemical studies. J. Comp. Pathol. 119(3):239-249.

Reguera M.J., Rabanal R.M., Puigdemont A. \& Ferrer L. 2000. Canine mast cell tumors express stem cell factor receptor. Am. J. Dermatopathol. $22(1): 49-54$. 
Rothwell T.L., Howlett C.R., Middleton D.J., Griffiths D.A. \& Duff B.C. 1987. Skin neoplasms of dogs in Sydney. Aust. Vet. J. 64(6):161-164.

Schlafer D.H. \& Miller R.B. 2007. Female genital system, p.429-564. In: Maxie M.G. (Ed.), Jubb, Kennedy, and Palmer's Pathology of Domestic Animals. Vol.3. Saunders Elsevier, Philadelphia.

Schrenzel M.D., Naydan D.K. \& Moore P.F. 1998. Leukocyte differentiation antigens in canine cutaneous and oral plasmacytomas. Vet. Dermatol. 9(1):33-41.

Sharkey L.C. \& Wellman M.L. 2011. Diagnostic cytology in veterinary medicine: a comparative and evidence-based approach. Clin. Lab. Med. 31(1):1-19.
Vos J.A., Abbondanzo S.L., Barekman C.L., Andriko J.W., Miettinen M. \& Aguilera N.S. 2005. Histiocytic sarcoma: A study of five cases including the histiocyte marker CD163. Mod. Pathol. 18(5):693-704.

Webster J.D., Kiupel M. \& Yuzbasiyan-Gurkan V. 2006. Evaluation of the kinase domain of c-KIT in canine cutaneous mast cell tumors. BMC. Cancer. 6:85. Available at <http://www.biomedcentral.com/1471-2407/ 6/85> Accessed on Dec. 20, 2010.

Yager J.A. \& Wilcock B.P. 1994. Tumors of the skin and associated tissues, p.239-313. In: Yager J.A. \& Wilcock B.P. (Eds), Color Atlas and Text of Surgical Pathology of the Dog and Cat: Dermatopathology and Skin Tumors. Vol.1. Wolfe, London. 